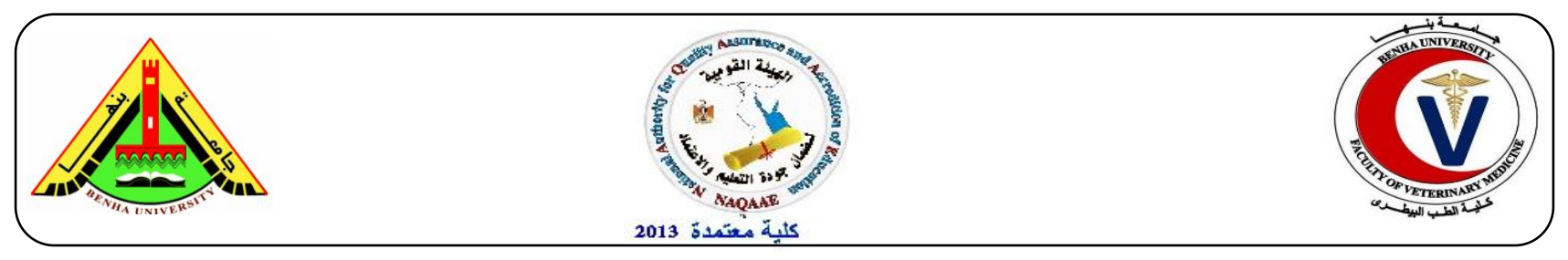

\title{
Phenotypic and Genotypic Characterization of E. Coli Isolated From Fish and Human
}

\author{
Ashraf A. AbdEl-Tawab, ${ }^{1}$ Fatma I. El-Hofy, ${ }^{1}$ Adel M.El-Gamal²andHeba O. Ibrahim ${ }^{3}$ \\ ${ }^{1}$ Bacteriology, Immunology and Mycology Department Faculty of Veterinary Medicine, Benha \\ University, Egypt. \\ ${ }^{2}$ BacteriologyDept, Animal Health Research Institute, Kafr El-Sheikh branch. Egypt. \\ ${ }^{3}$ Veterinary Medicine Directorate, Kafr El-Sheikh branch. Egypt
}

\begin{abstract}
A B S T R A C T
The present work aimed to isolate and characterize $E$. coli bacteria that transmitted from fish to fish handlers in markets and farm workers, for this 200 apparently healthy Oreochromis niloticus were collected randomly from different markets and farms and 50 human skin swabs from sellers at markets and workers at farms were obtained at Kafr El-sheikh governorate, Egypt. These samples were cultured and biochemical characters was studied. Serological identification, antibiogram activity and molecular characterization of some virulence factors were detected. Results, the prevalence of Escherichia coli was $17.5 \%$ in Tilapia while its prevalence in human was $24 \%$. Escherichia coli serotypes from fish were $\mathrm{O}_{153}: \mathrm{H}_{2}, \mathrm{O}_{1}: \mathrm{H}_{7}, \mathrm{O}_{125}: \mathrm{H}_{21}$ and $\mathrm{O}_{78}$. Only one from four isolates of Escherichia coli was positive to eaeA gene and the four isolates were negative to hly gene.
\end{abstract}

Key words: E. coli, biochemical, in vitro sensitivity, virulence genes, transmission, fish, human

http://www.bvmj.bu.edu.eg)

(BVMJ-34(2): 41-50, 2018)

\section{INTRODUCTION}

The most popular fresh water fish in Egypt are Oreochromis niloticus. The fish flesh, which is the main edible part, is generally sterile immediately after catching; however, it may become contaminated with different microorganisms during subsequent handling as these microorganisms can penetrate from skin and the gut to the flesh (El-olemy et al., 2014). Zoonotic diseases occurred during handling the affected fish (Magdy et al., 2014).
Escherichia coli in fish is considered as an indicator of sewage pollution. Most of the $E$. coli is normal inhabitants in the small intestine and they are non-pathogenic, meaning they do not cause disease in the intestine. E. coli spreads outside the intestine cause disease. The pathogenic strains of $E$. coli may cause diarrhea by producing and releasing toxins and cause deaths in fish (Soliman et al., 2010). 
Antibiotics used in both veterinary and human medicine include penicillins, cephalosporins, tetracyclines, chloramphenicols, amynoglycosides, spectinomycin, lincosamide, macrolides, nitrofurans, nitromidazoles, sulfonamides, trimethoprim, polymyxins, quinolones .However, evolution of bacteria towards resistance has been considerably accelerated by the selective pressure exerted by over prescription of drugs in clinical settings and their heavy use as growth promoters for farm animals such as fish.(Samuel et al., 2011)

Human infections caused by pathogens transmitted from fish or the aquatic environment are quite common depending on different reasons such as the season, patients' contact with fish, dietary habits and the immune system status of the exposed individual (Novotny et al., 2004).

With the increasing intensification of aquaculture production, diseases cause problems in the fish farming industry.Although vaccines are being developed and marketed but cannot be used as universal disease control measures in aquaculture. During the last decades, antibiotics used for fish diseases management, improvement of growth and efficiency of feed conversion (Denev et al., 2009).

So, The aim of this study is to detect, isolate and characterize $E$. coli transmitted from Oreochromis niloticus to fish handlers and farm workers.

\section{MATERIALS AND METHODS}

\subsection{Sampling:-}

\subsubsection{Fish samples:}

A total of 800 samples, 200 of each (gill, liver, spleen and kidney samples) from 200 apparently healthy 200 Tilapia niloticus were obtained randomly from some markets and farms in KafrEl-sheikh governorate (Egypt). 100 Tilapia fish were collected from markets and 100 from farms. Fish samples were placed in strong, clean and aseptic bags then packed in column and surrounded with ice bags and brought to laboratory on the day of collection to microbiological department, Animal health research institute, Kafrelsheikh Lab.

2.1.2. Human samples: A total of 50 human skin swabs (25 skin swabs from sellers at markets and 25 from workers at farms) were collected with $5 \mathrm{ml}$ saline to avoid dryness of samples and transported to the bacteriological lab to Microbiological department, Animal health research institute, Kafrelsheikh Lab.

\subsection{Bacteriological examination:-}

2.2.1.Isolation of $E$. coli from fishes: (Soliman et al., 2010)

Apiece of liver, spleen, kidney and gills were cultured separately on to MacConkey broth for isolation of $E$. coli. The MacConkey broth samples were streaked onto Eosine Methylene Blue agar for isolation of $E$. coli (selective plating) and incubated overnight at $37^{\circ} \mathrm{C}$.

2.2.2. Isolation of $E$. coli from human skin swab samples: (El-olemy et al., 2014)

Wetted human skin swab was inoculated separately in $5 \mathrm{ml}$ MacConkey broth, for isolation $E$. coli, the inoculated tubes were incubated at incubator. The MacConkey broth samples were streaked on to Eosine Methylene Blue agar plates, and incubated overnight at $37^{\circ} \mathrm{C}$.

\subsubsection{Biochemical identification:-}

The pure colonies of isolates were identified biochemically according to (Koneman et al., 1983 and Quinn et al., 2002).

Indole, Methyl red, Vogues-Proskauer, Simmon citrate and Triple sugar iron tests were done.

\subsection{Serological Identification of E.coli} serovars according to (Kok et al., 1996). 
- Two separate drops of saline were put on a glass slide and a portion of the colony from the suspected culture was emulsified with the saline solution to give a smooth fairly dense suspension.

- To one suspension, control, one loopful of saline was added and mixed. To the other suspension one loopful of undiluted antiserum was added and titled back and forward for one minute.

- Agglutination was observed using indirect lighting over a dark background. When a colony gave a strongly positive agglutination with one of the pools of polyvalent serum, a further portion of it was inoculated onto a nutrient agar slant and incubated at $37^{\circ} \mathrm{C}$ for 24 hours to grow as a culture for testing with mono-valent sera.

- A heavy suspension of bacteria from each slope culture was prepared in saline, and slide agglutination tests were performed with the diagnostic sera to identify the $\mathrm{O}$-antigen.

2.4.In-Vitro antibiotic sensitivity of bacteria according to Srivani (2001).

As shown in Table $(1,6)$. Subcultures from the isolates were prepared and the test was applied as follows:

A smooth single colony was inoculated in 5 $\mathrm{ml}$ nutrient broth and incubated at $37^{\circ} \mathrm{C}$ for 18 hrs, then turbidity was adjusted to 0.5 McFarland contain $\left(1.5 \times 10^{8}\right)$ colony forming unit/ml, then few drops of the inoculated broth were flooded on to the surface of Muller-Hinton agar plates. Excess of cultural fluid was removed aseptically and the plates were allowed to stand for 15 minutes at $37^{\circ} \mathrm{C}$ for dryness. Then the inoculated plates were over laid with antibiotic discs using a sterile forceps, the discs were distributed in a manner where the distance among them was optimum and away from the edge of plate to avoid overlapping of inhibition zones and give more wide area for the zone of inhibition. The inoculated plates were incubated at $37^{\circ} \mathrm{C}$ for 24 hours. The Inhibition zones, in $\mathrm{mm}$ were measured and scored as sensitive, intermediate and resistant categories with the critical break points recommends by CLSI (CLSI, 2011).

2.5. Detection of virulence factors of $E$. coli:.

Extraction of DNA according to QIAamp DNA mini kit instructions, Preparation of PCR Master Mix According to Emerald Amp GT PCR mastermix (Takara) Code No. RR310Akit,Cycling conditions of the primers during $\mathrm{CPCR}$ (temperature and time conditions of the two primers during PCR according to specific authors and Emerald Amp GT PCR mastermix (Takara) kit) they have specific sequence and amplify a specific product as shown in Table (2), DNA Molecular weight marker the ladder 100bp was mixed gently by pipetting up and down. 6 $\mu 1$ of the required ladder were directly loaded and agarose gel electrophoreses (Sambrook et al., 1989).

\section{RESULTS}

The morphological characters of the colonies on Eosine Methylene Blue were brilliant green. A total of 47 bacterial isolates were obtained from examined samples, 35 bacterial isolates from fish and 12 bacterial isolates from human. E.coli isolated from Tilapia with an incidence (17.5\%) as shown in (Table 3).

$E$. coli isolated from human with an incidence $(20 \%)$ of isolates were from sellers at markets and (28\%) from workers at farms. as shown in (Table 3 ).

$E$. coli give positive results to Indole, Methyl red and negative results to Vogues-Proskauer and simmons citrate. $E$. coli give yellow slant 
and yellow bottom without $\mathrm{H}_{2} \mathrm{~S}$ production as shown in Table (4).

Ten $E$. coli isolates were serotyped, six from Tilapia and four from human, serological identification revealed that five isolates from Tilapia were belonging to $\left(\mathrm{O}_{153}\right.$ $: \mathrm{H}_{2}, \mathrm{O} 1: \mathrm{H}_{7}, \mathrm{O}_{125} \quad: \mathrm{H}_{21}$ and $\left.2 \mathrm{O}_{78}\right)$. Three isolates from human belonging to $\left(\mathrm{O}_{153}: \mathrm{H}_{2}\right.$, $\mathrm{O}_{26}: \mathrm{H}_{11}$ and $\mathrm{O}_{78}$ ) as shown in (Table 5).

Antibiogram results revealed that E.coliO ${ }_{153}$, $\mathrm{O}_{1}$ isolates were resistant to Flumequine but $E_{\text {E.coliO }}{ }_{125}$ isolates were sensitive to Flumequine. E. coli $\mathrm{O}_{78}, \mathrm{O}_{26}$ isolates were resistant to Doxycillin but E.coliO 78 from human was resistant to Ciprofloxacin and Chloramphenicol. (Table 6).

Identification of eaeA and hly virulence genes of four $E$. coli isolates that were serotyped and the results revealed that only one isolate contain eaeA gene as shown in (Table 7) and(Figures 1,2).

Table (1): Effect of GSPE administration on serum glucose, urea and creatinine concentrations in streptozotocin induced diabetic nephropathy rats $(\mathrm{mg} / \mathrm{dl})$.

Data are presented as (Mean \pm S.E). $\quad$ S.E $=$ Standard error.

Mean values with different superscript letters in the same column are significantly different at $(\mathrm{P} \leq 0.05)$.

Table (1): Antimicrobial discs, concentration or antibiogram profile of antibiotic susceptibility of their action on the isolated E.coli.

$\begin{array}{ccccc}\begin{array}{c}\text { Susceptible } \\ (\mathrm{mm})\end{array} & \text { Intermediate } & \begin{array}{c}\text { Resistant } \\ (\mathrm{mm})\end{array} & \begin{array}{c}\text { Sensitivity disc } \\ \text { content }(\mu \mathrm{g})\end{array} & \text { Antimicrobial agent }\end{array}$

\begin{tabular}{lclcl}
14 or more & $12-13$ & 11 or less & 10 & Amoxicillin (AML) \\
19 or more & $15-18$ & 14 or less & 30 & Doxycyclin (DO) \\
18 or more & $13-17$ & 12 or less & 30 & Chloramphenicol (C) \\
20 or more & $15-19$ & 15 or less & 5 & Ciprofloxacin (CP) \\
23 or more & $14-22$ & 13 or less & 15 & Erythromycin (E) \\
15 or more & $12-14$ & 11 or less & 30 & Flumoquin (UB) \\
17 or more & $13-16$ & 12 or less & 30 & Neomycin (N) \\
29 or more & $21-28$ & 20 or less & 10 IU & Penicillin (P) \\
16 or more & $11-15$ & 10 or less & 25 & $\begin{array}{l}\text { Sulphamethoxazol } \\
\text { (SXT) }\end{array}$ \\
\hline
\end{tabular}

Table (2): Oligonucleotide primers sequences Source: Metabion (Germany). 


\begin{tabular}{ccccc}
\hline Target MO & Gene & $\begin{array}{c}\text { Sequence } \\
5-3\end{array}$ & $\begin{array}{c}\text { Amplified } \\
\text { product }\end{array}$ & Reference \\
\hline & & & & \\
& $e a e A_{R}^{F}$ & ATGCTTAGTGCTGGTTTAGG & $248 \mathrm{bp}$ & $\begin{array}{c}\text { Bisi-Johnson } \text { et al., } \\
(2011)\end{array}$ \\
E. coli & & GCCTTCATCATTTCGCTTTC & & Piva et al., (2003) \\
& $H l y_{R}^{F}$ & AACAAGGATAAGCACTGTTCTGGCT & $1177 \mathrm{bp}$ & \\
\hline
\end{tabular}

Table (3): Incidence of $E$. coli isolated from Tilapia and human.

\begin{tabular}{lll}
\hline \multirow{2}{*}{ Number of collected fishes and skin swabs from human } & \multicolumn{2}{c}{ Incidence of $E$. coli } \\
\cline { 2 - 3 } Total Tilapia $\mathrm{n}=200$ & 17.5 & 35 \\
Tilapia from farms $\mathrm{n}=100$ & 15 & 15 \\
Tilapia from markets $\mathrm{n}=100$ & 20 & 20 \\
Sellers from markets $\mathrm{n}=25$ & 5 & 20 \\
Workers from farms $\mathrm{n}=25$ & 7 & 28 \\
\hline
\end{tabular}

Table (4)Biochemical tests of $E$. coli:

\begin{tabular}{lccccc}
\hline Bacteria & \multicolumn{5}{c}{ Biochemical tests } \\
& Indole & $\begin{array}{c}\text { Methyl } \\
\text { red }\end{array}$ & $\begin{array}{c}\text { Voccus } \\
\text { prosqwer }\end{array}$ & $\begin{array}{c}\text { Citrate } \\
\text { utilization }\end{array}$ & TSI \\
E. coli & + & + & - & - & A/A -ve $\mathrm{H}_{2} \mathrm{~S}$ \\
\hline
\end{tabular}


Table (5): Results of serological identification of E.coli isolates.

\begin{tabular}{cccc}
\hline Serial & Identified Bacterium & Serodiagnosis & Strain \\
\hline 1 & $E \cdot \operatorname{coli}(\mathrm{F})$ & $\mathrm{O}_{153}: \mathrm{H}_{2}$ & EPEC \\
2 & $E \cdot \operatorname{coli}(\mathrm{F})$ & $\mathrm{O}_{1}: \mathrm{H}_{7}$ & EPEC \\
3 & $E \cdot \operatorname{coli}(\mathrm{F})$ & $\mathrm{O}_{125}: \mathrm{H}_{21}$ & ETEC \\
4 & $E \cdot \operatorname{coli}(\mathrm{F})$ & $\mathrm{O}_{78}$ & EPEC \\
5 & $E \cdot \operatorname{coli}(\mathrm{F})$ & $\mathrm{O}_{78}$ & EPEC \\
6 & $E \cdot \operatorname{coli}(\mathrm{H})$ & $\mathrm{O}_{153}: \mathrm{H}_{2}$ & EPEC \\
7 & $E \cdot \operatorname{coli}(\mathrm{H})$ & $\mathrm{O}_{26}: \mathrm{H}_{11}$ & EHEC \\
8 & $E \cdot \operatorname{coli}(\mathrm{H})$ & $\mathrm{O}_{78}$ & EPEC
\end{tabular}

(F) E.coli isolated from fish

(H) E. coli isolated from human

Table (6):Antimicrobials sensitivity results for $E$. coli isolates according to Srivani (2001).

\begin{tabular}{|c|c|c|c|c|c|c|c|c|c|}
\hline Antimicrobial agents & $\begin{array}{c}\text { Diffusio } \\
\text { n zone } \\
\text { break } \\
\text { point } \\
(\mathrm{mm})\end{array}$ & 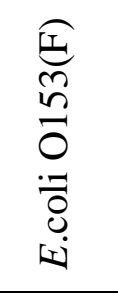 & 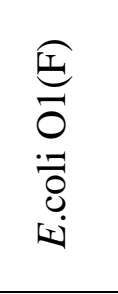 & 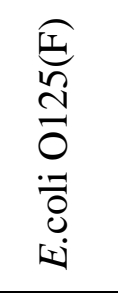 & $\begin{array}{l}\underset{1}{0} \\
0 \\
0 \\
:=1 \\
0 \\
0 \\
ن\end{array}$ & 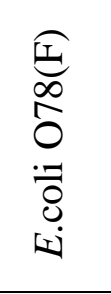 & 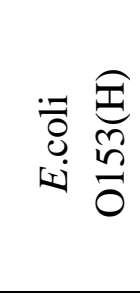 & 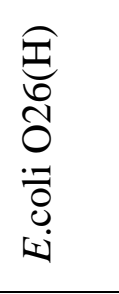 & 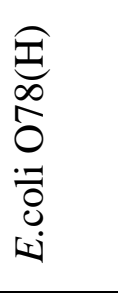 \\
\hline Penicillin $(\mathrm{P})$ & $20 \leq$ & $29(\mathrm{~S})$ & $31(\mathrm{~S})$ & $30(S)$ & $21(\mathrm{I})$ & $23(\mathrm{I})$ & $28(\mathrm{~S})$ & $33(\mathrm{~S})$ & $30(S)$ \\
\hline Amoxicillin(AML) & $14 \leq$ & $20(S)$ & $19(\mathrm{~S})$ & $21(\mathrm{~S})$ & $19(\mathrm{~S})$ & $19(\mathrm{~S})$ & $21(\mathrm{~S})$ & $19(\mathrm{~S})$ & $22(\mathrm{~S})$ \\
\hline Ciprofloxacin(CP) & $12 \leq$ & $17(\mathrm{~S})$ & $5(\mathrm{R})$ & $8(\mathrm{R})$ & $15(\mathrm{I})$ & $19(\mathrm{~S})$ & $16(\mathrm{I})$ & $19(\mathrm{~S})$ & $11(\mathrm{R})$ \\
\hline Chloramphenicol(C) & $15 \leq$ & $18(\mathrm{~S})$ & $10(\mathrm{R})$ & $8(\mathrm{R})$ & $16(\mathrm{I})$ & $17(\mathrm{I})$ & $15(\mathrm{I})$ & $15(\mathrm{I})$ & $4(\mathrm{R})$ \\
\hline Erythromycin(E) & $13 \leq$ & $23(\mathrm{~S})$ & $24(\mathrm{~S})$ & $25(\mathrm{~S})$ & $11(\mathrm{R})$ & $3(\mathrm{R})$ & $5(\mathrm{R})$ & $8(\mathrm{R})$ & $22(\mathrm{~S})$ \\
\hline Doxacillin(DO) & $16 \leq$ & $17(\mathrm{I})$ & $20(S)$ & $17(\mathrm{I})$ & $21(S)$ & $20(S)$ & $19(\mathrm{~S})$ & $17(\mathrm{I})$ & $20(S)$ \\
\hline Neomycin(N) & $12 \leq$ & $19(S)$ & $18(S)$ & $17(S)$ & $31(\mathrm{I})$ & $19(S)$ & $18(S)$ & $19(S)$ & $19(S)$ \\
\hline Flumquine(UB) & $15 \leq$ & $18(\mathrm{~S})$ & $13(\mathrm{I})$ & $20(S)$ & $6(\mathrm{R})$ & $21(S)$ & $22(\mathrm{~S})$ & $8(\mathrm{R})$ & $17(\mathrm{~S})$ \\
\hline $\begin{array}{l}\text { Sulphamethoxazol+t } \\
\text { rimethoprime(SXT) }\end{array}$ & $10 \leq$ & $8(\mathrm{R})$ & $4(\mathrm{R})$ & $16(S)$ & $18(\mathrm{~S})$ & $12(\mathrm{I})$ & $19(\mathrm{~S})$ & $20(S)$ & $20(S)$ \\
\hline
\end{tabular}

(F)Bacteria isolated from fish

(H) Bacteria isolated from human 
Table (7): Results of molecular identification of eaeA and Hlygene of E. coli.

\begin{tabular}{|c|c|c|c|}
\hline \multicolumn{2}{|c|}{ Results } & \multirow{2}{*}{ Sample } & \multirow{2}{*}{ Target MO } \\
\hline Hly & $e a e A$ & & \\
\hline$-\mathrm{ve}$ & -ve & 1 & \multirow{4}{*}{ E. coli } \\
\hline -ve & $+v e$ & 2 & \\
\hline -ve & -ve & 3 & \\
\hline -ve & -ve & 4 & \\
\hline
\end{tabular}

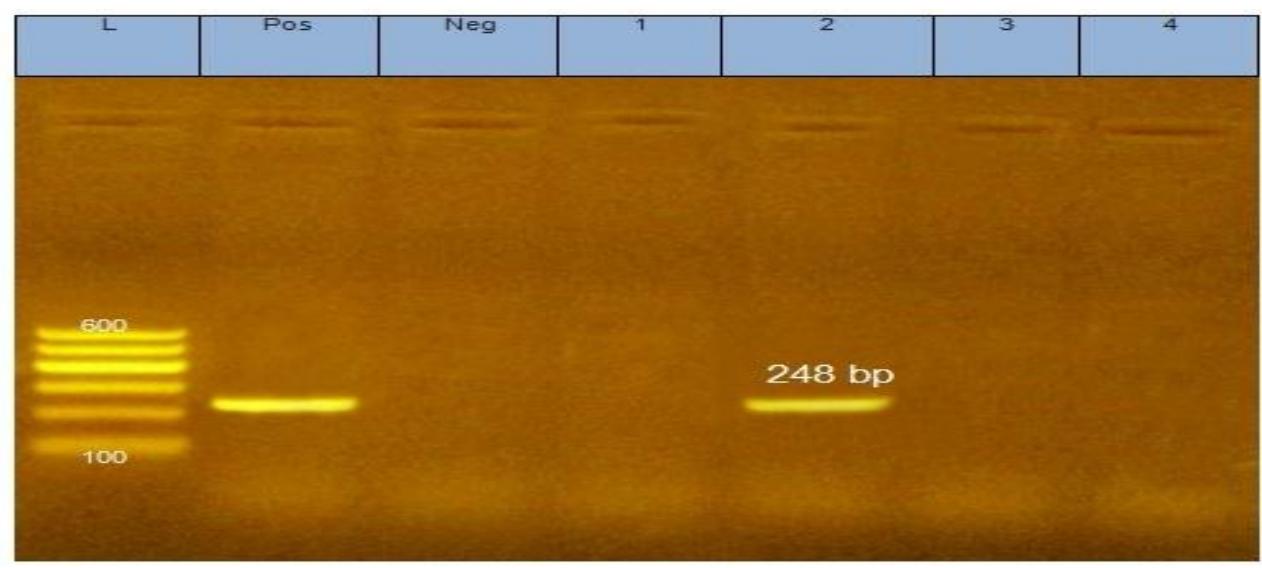

Figure (1): Agrose gel electrophoresis of PCR amplified products of virulence gene. Lane L: DNA molecular size marker (100bP), lane Neg: Negative control, lane Pos: Positive control, lane 2: eaeA virulence gene of $E$. coli. The size in base pairs (248bP) of PCR product is indicated for the bands.

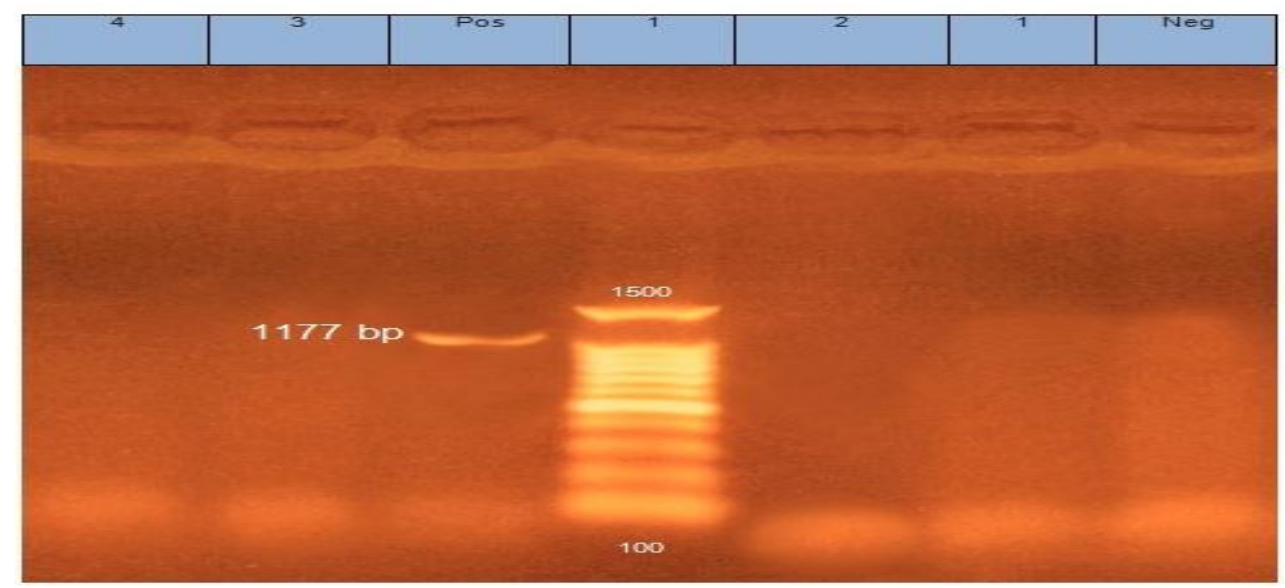

Figure (2): Agrose gel electrophoresis of PCR amplified products of virulence gene. Lane L: DNA molecular size marker (100bP), lane Neg: Negative control, lane Pos: Positive control of Hly virulence gene of E.coli. The size in base pairs (1177bP) of PCR product is indicated for the bands. 
There are a variety of types of $E$. coli. $E$. coli is a bacterium that commonly lives in the intestine of people, animal and fish. There are many strains (types) of $E$. coli. Most of the $E$. coli are normal inhabitants in the small intestine and colon and they arenonpathogenic, meaning they do not cause disease in the intestine. Soliman et al. (2010).

E. coli isolated from Oreochromis niloticus with an incidence of (17.5\%) as shown in(Table 3). These results partial agree with Saqr et al. (2016) reporting incidences (18.3\%). Higher incidences of E.coli were recovered by Amr et al. (2012), David et al. (2009), Galal et al. (2013)and Gupta et al. (2013) who reported incidences of $E$. coli $50 \%, 57.1 \%, 29.34 \%$ and $36 \%$ respectively. But Atwa (2017) isolated E. coli from skin, muscle, intestine and liver with incidences 25 , $22.5,25$ and $35 \%$ respectively.

E.coli isolated from human with incidence of $(20 \%)$ from sellers in markets and $(28 \%)$ from workers in farms as shown in (Table 3). The results partially similar with El-olemy et al. (2014) reporting incidences (20\%) from fish handlers and $(37.5 \%)$ from house wifes.

Ten E.coli isolates were serotyped (six from Tilapia and four from human). Serotyping revealed that five isolates from Tilapia were belonging to $\left(\mathrm{O}_{153}: \mathrm{H}_{2}, \mathrm{O}_{1}: \mathrm{H}_{7}\right.$, $\mathrm{O}_{125}: \mathrm{H}_{21}$ and $2 \mathrm{O}_{78}$.) and three isolates from human belonging to $\left(\mathrm{O}_{153}: \mathrm{H}_{2}, \mathrm{O}_{26}: \mathrm{H}_{11}\right.$ and $\mathrm{O}_{78}$ ) as shown in(Table 5). But Barbosa et al. (2014) by serological identification of $49 \mathrm{E}$. coli revealed that the most common serogroups were $\mathrm{O}_{125}: \mathrm{H}_{21} \quad \mathrm{O}_{126}: \mathrm{H}_{11}$ and $\mathrm{O}_{158}: \mathrm{H}_{2}$.
In this study as mentioned at (Table 6). E.coli $\mathrm{O}_{153}: \mathrm{H}_{2}$ strain isolated from fish and human, $E$. coli $\mathrm{O}_{125}: \mathrm{H}_{21}$ andE.coli $\mathrm{O}_{78}$ isolated from fish and $E$. coli $\mathrm{O}_{26}: \mathrm{H}_{11}$ were resistant to Doxicyclin. E. coli $\mathrm{O}_{78}$ strain isolated from human were resistant to Ciprofloxacin and Chloramphenicol. Soliman et al. (2010) reported that $E$.coli isolates were sensitive to Enrofloxacine, Oxanilic acid and Spectinomycine. Our results disagree with Samuel et al. (2011) who explained that there is no $E$. coli shows resistance to Norfloxacine, Sulphamethoxazol+ trimethoprim and Chloramphenicol.

Only one isolate of E.coli contain $e a e A$ virulence gene of $E$.coli and none of the isolates contain $H l y$ virulence gene of $E$. coli. Examination of $e a e A$ virulence gene of $E$. coli giving PCR product of (248) bP size as shown in (Table 7). The prevalence of eaeA virulence gene of $E$. coli was $25 \%$. And this agrees with Kargar and Hamayoon (2015) as they recorded only one isolate from seven isolates of $E$. coli $\mathrm{O} 157: \mathrm{H} 7$ contains eaeA virulence gene of $E$. coli but not has hlyA virulence gene of $E$. coli. But Aljanaby and Alfaham (2017) revealed that the lower prevalence of virulence genes in E.coli were (4\%) of eaeA and stxl virulence gene of E.coli.

\section{CONCLUSION}

We can concluded that the most important Escherichia coli serotypes causing severe losses in fish are $\mathrm{O}_{153}: \mathrm{H}_{2}, \mathrm{O}_{1}: \mathrm{H}_{7}, \mathrm{O}_{125}$ : $\mathrm{H}_{21}$ and $\mathrm{O}_{78}$ these bacteria can transmitted to human and cause disease. E.coliO ${ }_{153}: \mathrm{H}_{2}$, $\mathrm{O}_{1}: \mathrm{H}_{7}$ isolates were resistant to Flumequine but $E$.coliO ${ }_{125}: \mathrm{H}_{21}$ isolates were sensitive to Flumequine. E. coli $\mathrm{O}_{78}, \mathrm{O}_{26}: \mathrm{H}_{11}$ isolates were resistant to Doxycillin but $E \cdot$ coliO $_{78}$ from 
human was resistant to Ciprofloxacin and Chloramphenicol.

\section{REFERRENCES}

Aljanaby, A.A.J. and Alfaham, Q.M. 2017. Phenotypic and molecular characterization of some virulance factors in multidrug resistance Escherichia coli isolated from different clinical infections in Iraq. American Journal of Biochemistry and Molecular Biology, 7(2):65-78.

Amr, A.A. ;Hosam, A.A. ; and Heba, R.M. 2012. Enteropathogen of some fresh water fish. Alex J. Vet. Science, 37(1):49-52.

Atwa, E.I. 2017. Bacteriological study of fish samples collected from different markets in some Egyptian Governorates and antimicrobial sensitivity of isolates. Int. J. Curr. Microbiol. App. Sci. 6(5):2765-2776.

Barbosa, M.M. ; Pinto, F.D. ; Ribeiro, L.F. ; Guriz, C.S. ; Maluta, P.R. ; Rigobelo, E.C. ; Avila, F.A. and Amaral, L.A. 2014. Serology and patterns of antimicrobial susceptibility in Escherichia coli isolates from pay- tofish ponds. Arq. Int. Biol. Sao Paulo, 81(1):43-48.

Bisi-Johnson, M.A. ;ObiCL ;Vasaikar, S.D. ; Baba, K.A. and Hattori, T. 2011. Molecular basis of virulence in clinical isolates of Escherichia coli and Salmonella species from a tertiary hospital in the Eastern Cape, South Africa. Gut Pathogens, 3:9.

David, O.M. ;Wandili, S. ; Kakai, R. and Waindi, E.N. 2009. Isolation of Salmonella and Shigella from fish harvested from the winam gulf of lake Victoria, Kenya. J. infect developing countries, 3(2):99-104.
Denev, S. ;Staykov, Y. ; Moutafchieva, R. and Beev, G. 2009. Microbial ecology of the gastrointestinal tract of fish and the potential application of probiotics and prebiotics in finfish aquaculture. Int. Aquat. Res, 1: 1-29.

El-olemy, G.M.; Lobna, M.A.; Salem, N. ;Khalifa, O. and Abd el wahab, M.S. 2014. Detection of some bacterial zoonosis in market fish in Qalyoubia province and their control.Benha Veterinary Medical Journal, 26(2):126-136.

Galal, H.M,; Hakim, A.S. and Dorgham, S.M. 2013. Phenotypic and virulence genes screening of Escherichia coli strains isolated from different sources in delta Egypt, Life science journal, 10(2):352-361.

Gupta, B.; Ghatak, S. and Gill, J.P.S. 2013. Incidence and virulence properities of E.coli isolated from fresh fish and ready-to-eat fish products. Vet world, 5-9.

Kargar, M. and Hamayoon, M. 2015. Prevalence of shiga toxins (stxl,stx2), $e a e A$ and hly genes of Escherichia coli O157:H7 stains among children with acute gastroenteritis in southern of Iran. Asian Pacific Journal of tropical medicine, 24-28.

Kok, T. ;Worswich, D. and Gowans, E. 1996. Some serological techniques for microbial and viral infections.In Practical Medical Microbiology (Collee, J.; Fraser, A.; Marmion, B. and Simmons, A., eds.), 14th ed., Edinburgh, Churchill Livingstone, UK.

Koneman, E.W. ; Allen, S.D.; Dowell, V.R. and Summers, H.W. 1983. Color atlas and text book of diagnostic 
microbiology. 2nd Ed. J.B. Lippincott, New York, London.

Magdy, I.H. ;Elhadi, M.A. ; Ahmed, H.A. ; Elmeadawy, S.A. and Kenwy, A.M. 2014. A contribution on Pseudomonas aeruginosa infection in African Catfish (Claris gariepinus).Research Journal of Pharmaceutical, Biological sciences, 5(5):575-588.

Novotny, L.; Dvorska, L. ;Lorencova, A.; Beran, V. and Pavlik, L. 2004. Fish: A potential source of bacterial pathogens for human beings. Vet. Med. Zech, 49(9): 343-358.

Piva, I.C. ; Pereira, A.L. ;Ferraz, L.R.; Silva, R.S.N. ; Vieira, A.C. ; Blanco, J.E. ; Blanco, M. ; Blanco, J. and Giugliano, L.G. 2003.Virulence Markers of Enteroaggregative Escherichia coli isolated from children and adults with diarrhea in Brasília, Brazil. Journal of Clinical Microbiology, p. 1827-1832.

Quinn, P.J. ; Carter, M.E. ; Markey, B.K. ; Donnelly, W.J.C. and Leonard, F.C. 2002. Veterinary Microbiology and Microbial diseases. MPG.Book 1st ed. Bodmin, Cornwall, UK.

Sambrook, J. ;Fritscgh, E.F. and Mentiates .1989. Molecular coloning.A laboratory manual. Vol !., Cold spring Harbor Laboratory press, New York.

Samuel, L. ; Marian, M.M. ; Apun, K. ; Lesley, M.B. and Son, R. 2011. Characterization of Escherichia coli isolated from cultured Catfish by antibiotic resistance and RAPD analysis. International food research journal, 18(3):971-976.

Saqr, S. ;Khalie, R. and Ibrahim, M.S. 2016. Antibiotic resistance and virulence genes of $E$. coli isolated from fresh Nile tilapia (Oreochromis niloticus) in El- Behera Governorate, Egypt.
Alexandria journal of veterinary science, 48(2):83-90.

Soliman, M.k. ; Khalil, R.H. ; Saad, T.T.; ElGamal, M.H.L. and Gebrail, A.E. 2010. Isolation and identification of E.coli from cultured fresh water. Journal of the Arabian aquaculture society, 5(1):19-34.

Srivani, R. 2001. Studies on antimicrobial susceptibility pattern of Salmonella isolates from Chennai, India. Inter. J. Pharma and Bio Sciences, 2: 435 442. 